\title{
PROCESS MANAGEMENT IN RUSSIAN BUSINESS EDUCATION
}

\author{
Svetlana Korobeynikova, Ludmila Dukanich, The Russian Presidential Academy of National \\ Economy and Public Administration - Graduate School of Corporate Management, ludmila@emba.ru
}

The current management system in Russian business education is predominantly based on the principle of functional management, which in turn does not comprehensively address the emerging objectives and terms of modern-day education providers in Russia. The countries' business schools are of the particular concern of the issue, considering the factors of their recent establishment and revenue-based financing. Presented in this paper is the outcome of implementation of the process-orientated approach to business education based on the experience of one of the leading Russian business schools. The implementation of the process-orientated approach into the management system of the business school has resulted in an array of advantages: a significant improvement in the speed of the management process; a horizontal and vertical compaction of processes due to employees making independent decisions, reduction in the number of errors, delays and alterations, an increase in the quality of tasks executed by the personnel, a decrease in the need of employee monitoring; reduction of costs associated with employee wages and equipping workplaces; development of the basis for automation of educational and supporting business processes and delegation of particular elements of business processes to external.

JEL Classification Number: M10, DOI: 10.12955/cbup.2013.33

Key words: line of business, business process, objectives of business processes, proprietors of business process, responsibility matrix

\section{Introduction}

The Russian education system is currently in the process of profound transformation. The mobility, flexibility and continuity orientation of the current education system does not only demand the rethinking of its goals and objectives on the substantial level, but also the change in structure and methods of education processes management. This also applies to the relatively new type of educational services in Russia, business education (The Russian Presidential Academy of National Economy and Public Administration, 2009).

With Russia's shift to market economy, business schools and other providers engaged in business education were established as commercial entities, hence having to function as businesses and obey market principles. The implementation of modern-day approaches to management, allowing for a more effective use of human and financial resources and providing a high standard of education while retaining the substantial levels of revenue is vital for such entities. 


\section{The Process Management Approach}

Currently, process management approach, according to which management is seen as a continuous series of interconnected management processes is recognized as one of the most prospective. The effectiveness of the approach is supported by a number of Russian and international researchers, such as Filinovich (2004), Ermakova (2009), Porter (2001), Hammer and Champy (2007) and Repin (2007). The management of business education in Russia, however, is still primarily based on the functional approach, which does not provide for proper flexibility or effectiveness under conditions of transmission to a new educational model.

With the process management approach, the management entities are the processes, which can pass through a number or even all departments of the education provider (business school), focusing on the final outcome - proficiency and acquisition of a set of competencies and skills, determined by the standards of education. The vital difference of such approach is that the management entities are processes and not the structural-functional units of the management system. The business school, therefore, is perceived as a structured in a certain way set of processes, and the management of such entity is the management of the aggregate of interconnected business processes.

The specificity of educational management process closely relates to the division of management processes introduced by M. Porter: principal processes (in this case - the production and implementation of the educational service), supporting processes (supporting the principal processes, such as logistics, information provision etc.) and management processes (establishment of goals and forming conditions to achieve them). Principal processes create the added value of the product, the product itself, form the outcome and the consumer-oriented qualities; they are aimed at generating revenue. (Porter, 2001) The principal processes in educational institutions are planning, development and implementation of educational programs, student admission, scientific research and development etc. One of the examples of a business process is a process of "Selection and Recruitment of Personnel".

\section{The stages of process management implementation}

As stated by Kovalev (2006), Hammer and Champy (2007) and Ermakova (2012), process-oriented approach is implemented in a number of steps:

1. Allocation of a business-line of the organization, outlining the business processes involved.

2. Modelling a business process tree.

3. The description of divisions implementing the business processes.

4. Evaluation and selection of business processes for further detailed description, analysis and optimization (this generally concerns the principal business processes, or business processes which after the analysis have been classified as bottlenecks).

5. Processing and forming guidelines and flowcharts of business processes, highlighting the information flows.

\section{The definition of the line of business, key parties and the environment for the business school in question}

For a business school (providing a full range of services in the field of business education), chosen to pilot the implementation of the process approach, the following lines of business have been chosen: 
MBA programs (with certain forms of implementation - part-time, modular, remote); DBA (Doctor of Business Administration) program; employee retraining program; corporate program; short-term seminars and trainings. The selection of the line of business allowed separating and then structuring the business processes of the business school in question.

The vital element of process management is the evaluation and definition of each key interested parties of the line of business, and hence the business process. They include: clients (students of the program), service providers for the line of business, partners, government agencies of a different scale, mass media etc. Each interested party is defined with a number of parameters, the most important of which are the needs of the party, party's valuation of the line of business, and the value of each party for the business school. Then, the principal and supporting processes for each principal and supporting business activities are determined and set.

When each business process is defined, it is designated with a name, an identified beginning and end, the proprietor of a business process and an objective, which measures the effectiveness of the process by the extent, an objective has been met. The proprietor of the process bears the sole responsibility for meeting the objective, which is vital in order to improve the quality of education.

The environment of the business process is then determined, with the aggregate of inputs and outputs (primary - significant and secondary - insignificant), listing suppliers and clients. Primary input is the input initiating the process. Primary output is the principal result, the reason every business process exists (refer to Table 1 and 2). When the environment of the business process is determined, the internal structure of the business process is to be determined (vertically or horizontally).

The vertical description illustrates the actions, which the business process consists of. The horizontal description illustrates the interactions between the actions, including the financial and informational flows. Today, there are a number of approaches and standards to model business processes, such as ARIS, IDEF0, DFD, WFD and others. (Ermakova, 2009; Blinov et al., 2010; Bekker et al., 2010)

Each process can then be detailed, or divided by subprocesses if needed. As an example, the business process of intake of students, which acts as one of the vital processes in the business and is at the same time universal for all lines of business of the business school, the following subprocesses have been distinguished:

1. Discussion and making of the decision on the date of intake, the cost of the program and the number of students.

2. Informing the marketing department of the need of advertising.

3. Receipt of applications and preparation of documents for registration of admission.

4. Receipt of documents from students.

5. Drafting of an agreement of providing educational services.

6. Final formation of a group of students.

\section{Management processes reengineering following the implementation of a process- orientated management system}

The structured, detailed management processes of the business school provided the following outcomes: 


\section{Structure}

1.1. Organizational structure

1.2. Financial structure

\section{Finance}

\subsection{Financial planning}

2.2. Maintaining operating budgets

2.3. Maintaining the budget of revenue and expenditures

2.4. Maintaining the cash flow budget

2.5. Operational budget

\section{Marketing}

3.1. Market, competition and potential customer analysis

3.2. Marketing research

\subsection{Client search}

3.4. Forming the businesses' informational background

\subsection{Pricing}

\section{Personnel management}

\subsection{Selection and recruitment of personnel}

\subsection{Personnel management.}

\section{The definition of "Selection and Recruitment of Personnel" as a supporting business process and the specification of its subprocesses}

Let the process of "Selection and Recruitment of Personnel", implemented in the course of the reengineering of the management process in the considered business school act as an example of a definition of a process. The purpose of the definition of this process is to increase the efficiency of the process of "Selection and Recruitment of Personnel" in order for it to conform to the objectives and obligations, determined by the common goal. Purpose of the process is to provide the business school with qualified personnel and to fill all staffing vacancies, while allowing for the specifics of the activities of such educational provider. The environment of this business process, the inputs and outputs, as well as suppliers and clients of the process are presented in the Tables 1 and 2. For such business process, two business process borders can be derived: the beginning of the business process the receipt of a request from an operating unit, and the end of business process - the appointment of an employee to a position.

For the above process, the following have been classified as subprocesses:

1. The receipt of a request of a vacant position in a structural subdivision, with a list of requirements for applicants.

2. The publishing of information about the available vacancy in various sources.

3. The primary selection based on the resume analysis and additional information about the candidate. 
4. Conducting interviews with candidates.

5. Secondary selection.

6. Registration of labor relations.

Table 1: Inputs and suppliers of the business process, "Selection and recruitment of the personnel"

\begin{tabular}{|c|c|}
\hline Primary inputs & Primary suppliers \\
\hline The request of the availability of the vacancy & Structural unit \\
\hline Secondary inputs & Secondary suppliers \\
\hline Candidate & Labor market \\
\hline Resume & $\begin{array}{c}\text { Candidate, recruitment agency, employment } \\
\text { service }\end{array}$ \\
\hline Contact with the candidate & Deputy Dean of business school \\
\hline
\end{tabular}

Source: Authors

Table 2: Outputs and customers of the business process, "Selection and recruitment of the personnel"

\begin{tabular}{|c|c|}
\hline Primary outputs & Primary clients \\
\hline Filled vacancy & Structural unit \\
\hline Secondary outputs & Secondary clients \\
\hline $\begin{array}{c}\text { Order, employment record book, personal } \\
\text { data file }\end{array}$ & Recruitment archive \\
\hline Information on refusal & Candidate \\
\hline Vacancy announcement & $\begin{array}{l}\text { Mass media, business school website, job } \\
\text { search web services, recruitment agencies }\end{array}$ \\
\hline
\end{tabular}

Source: Authors

Process management technology further includes the preparation and analysis of the diagram of the environment of each business process, which illustrates the movement of inputs, suppliers, outputs and customers of the process in their interrelations. The functional structure of the business process is then outlined, which determines the sequence of all actions a business process should consist of in detail. For subprocess "Initial selection based on the analysis of the resume and other information about the candidate," the following sequence is established:

1. The selection and review of the resumes.

2. The selection of candidates by phone calls and e-mail requests.

3. The appointment of the meeting.

Then, the movement of the flows of objects in the business process (the information flows on various mediums) is considered and fixed. The following is an example of the structure of an object flow of the illustrated the business process. 
CBU INTERNATIONAL CONFERENCE ON INTEGRATION AND INNOVATION IN SCIENCE AND EDUCATION

Table 3: The structure of object flow of the "Selection and recruitment of the personnel" business process

\begin{tabular}{|c|c|c|}
\hline $\begin{array}{l}\text { Paper-based information } \\
\text { (documents) }\end{array}$ & Oral information & $\begin{array}{c}\text { Information in electronic } \\
\text { format }\end{array}$ \\
\hline $\begin{array}{c}\text { Request } \\
\text { Representation } \\
\text { Paper-based candidate's } \\
\text { resume } \\
\text { Order, employment record } \\
\text { book } \\
\text { Dean's decision on admission }\end{array}$ & $\begin{array}{c}\text { Request to the candidate } \\
\text { Phone call } \\
\text { Oral comments } \\
\text { Information on refusal } \\
\text { Contact with the candidate }\end{array}$ & $\begin{array}{l}\text { Vacancy announcement } \\
\text { Resume in the electronic } \\
\text { format }\end{array}$ \\
\hline
\end{tabular}

\section{The responsibility matrix as an effective tool of integration of the management approach}

For the successful implementation of a business process and for obtaining of the effective results, it is necessary to distribute the responsibility for the execution of each subprocess. For this purpose, a list of organizational units of the business process is compiled (in this case - a business school Dean, Deputy Dean, Head of structural unit, marketing manager, human resources employee). Based on this list a responsibility matrix is composed.

Table 4: Business process responsibility matrix

\begin{tabular}{|c|c|c|c|c|c|c|}
\hline $\begin{array}{l}\text { The main stages of the } \\
\text { business process } \\
\text { Organizational structure of } \\
\text { the business process }\end{array}$ & 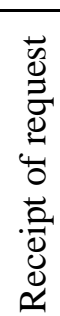 & 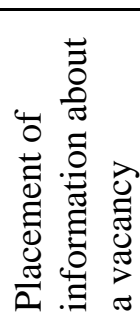 & 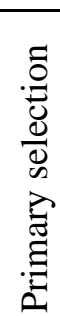 & 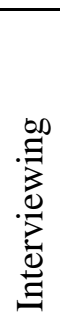 & 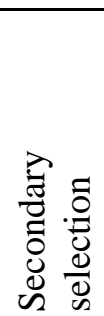 & 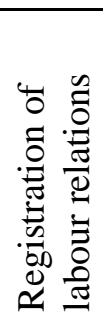 \\
\hline Business school Dean & & & & & $\mathrm{X}$ & \\
\hline $\begin{array}{l}\text { Deputy Dean of business } \\
\text { school }\end{array}$ & & & $\mathrm{X}$ & $\mathrm{X}$ & & \\
\hline Head of structural unit & $\mathrm{X}$ & & & & & \\
\hline Marketing manager & & $\mathrm{X}$ & & & & \\
\hline HR employee & & & & & & $\mathrm{X}$ \\
\hline
\end{tabular}

Source: Authors

Responsibility Matrix graphically illustrates which of the employees is responsible for certain stages of the process, thus allowing to relieve the management of some part of responsibility and to delegate certain amount of work to another employee in order to improve efficiency. The final stage in the description of the business process is the development of its scheme. Schematic illustration of the process clearly demonstrates the entire set of actions performed, taking the alternative solutions into account. 


\section{Conclusion}

It should be noted that the selection and description of business processes requires painstaking effort (it's much easier to mark structural units), and above all the political will of the business school management. However, the implementation of the process approach can greatly increase the effectiveness of the educational activity. The qualitative changes in the business school's management processes are evident after the implementation of such procedure. These include the following:

- while maintaining the simplicity of the processes, several positions are combined into one, thereby reducing the costs of labour and equipment for the workplace of the employee;

- an increase in the speed of the execution of the process, reduction of the number of errors, delays and reworks;

- the motivation of the staff to improve the quality of their assignment is formed, which reduces the necessity of control and as a result reduces the overhead expenses;

- employees by making independent decisions provoke horizontal and vertical compression of the process;

- the rejection of strict linearity in favour of the natural order of the execution of the processes results in a significant acceleration of the management process;

- the number of reconciliations between units is reduced;

- the process concentrates in the hands of one employee, which leads to him becoming the only contact for the course taker. This improves the quality of service and image of a business programme, increases customer loyalty.

The practice of the process approach allows solving another long-run problem - automation and active implementation of the Internet technologies in the management of the organization as a major educational and supportive business processes in this domain.

The perspective of transferring single items of business processes to external contractors on the principles of outsourcing and crowdsourcing is an even more attractive perspective in terms of process management. Pre-defining the parameters of business processes that affect their value for the consumer may be helpful for attracting a virtually unlimited number of the performers on a competitive basis and remotely controlling them. These areas may include: processes of crediting students by a variety of financial institutions, the formation of a contingent of course takers with the assistance of recruitment agencies, as well as the recruitment of the higher education teaching personnel from around the world.

\section{References}

Bekker, Y., Vilkova, L., Taratuhina, V., Kugler, M. \& Rossmann M. (2010). Managment processov [Process management]. Moscow, Russia: Eksmo.

Blinov, A. O. (2010). Reengineering bisness-processov [Business process reengineering]. Moscow, Russia: Unity-Dana.

Ermakova, S. (2009). Upravlenie bisness-processarmi v medicinskoy organizacii [Business process management in the medical organisation]. Moscow, Russia: MAKS Press. 
Ermakova, S. (2012). Healthcare modernization. Process-orientated management system. Saarbrücken, Germany: Lambert Academic Publishing.

Filinovich, S. R. (Ed.). (2004). Bisness-obrasovanie: specifica, programmyu, technologii, organizaciya. [Business Education: specific, software, technology, business]. Moscow, Russia: HSE Publishing House.

Hammer, M. \& Champy, J. (2007). Reengineering bisnessa. Manifest revoluziyi v bisnesse.

[Reengineering the Corporation. A Manifesto of Business Revolution]. ( $2^{\text {nd }}$ ed.). Moscow, Russia: Publishing House of Mann, Ivanov and Ferber.

Kovalev, S. M. (2006). Bisness-processi, osnovnye standartiy ih opisaniya [Business processes, the basic standards of their description]. Directory of the economist, Vol. 11.

Porter, M. (2001). Konkurenciya [On Competition]. Kiev, Ukraine: Williams.

Repin, V. V. (2007). Bisness-processi v companii. Postroeniye, analis, reglamentaciya [Business process within an organisation: implementation, analysis, regulation]. Moscow, Russia: Publishing House Standards and quality.

The Russian Presidential Academy of National Economy and Public Administration. (2009). Russian education: trends and challenges. A collection of articles and analytical reports. Kiev, Ukraine: Delo Publishing House. 